\title{
Human Rights and Equality
}

\author{
CHRISTOPHER MCCRUDDEN
}

\subsection{Introduction}

Human rights and equality issues were a critical part of the negotiation of the 1998 Belfast-Good Friday Agreement (hereafter 1998 Agreement) and contributed to the successful outcome of those negotiations. Leading up to and following the 1998 Agreement, there was a flurry of domestic legislative activity, in particular the Human Rights Act 1998, the Fair Employment and Treatment Order 1998 and the Northern Ireland Act 1998. This is no coincidence: the Agreement was intended largely to be a framework for such activity, and a statement of principle, rather than to be directly enforceable. When taken together with previous legislation on equality beginning in the 1970s, and with subsequent legislation during the 2000s, Northern Ireland now has one of the more impressive collections of human rights and equality law in Europe. It is noteworthy that all this legislation was enacted either at Westminster or by UK government ministers under powers to legislate during periods of 'direct rule', when the Assembly was suspended. This legislation was supplemented yet further with 'social' legislation (in particular in the employment and welfare fields), a degree of protection from discrimination on the basis of citizenship arising from the operation of the Common Travel Area (CTA), ${ }^{1}$ and fitful use of public procurement 'linkages' to add extra financial weight to ensure compliance. ${ }^{2}$

Even before the 2016 Referendum had been held, concerns had been expressed that the exit of the UK from the EU could lead to a reduction in the level and intensity of these protections because EU law to a degree provided underpinnings through Treaty provisions (eg, on equal pay), the anti-discrimination directives (race, sex, age, sexual orientation, disability), the 'social' directives (part-time work, maternity/paternity, etc), political

1 See Chapter 14.

2 See Chapter 22. 
obligations regarding the European Convention on Human Rights (ECHR), the Charter of Fundamental Rights (CFR) and the status of EU citizens (including EU citizens by virtue of being Irish citizens). Common membership of the EU also meant that a greater degree of convergence between Northern Ireland and Ireland was emerging in those areas where EU law was influential.

The Withdrawal Agreement (WA) addresses human rights and equality concerns directly and indirectly in three main ways: (i) the provisions in Part 2 WA dealing with reciprocal rights for EU citizens residing in the UK and UK citizens residing in the EU protect Irish citizens residing in Northern Ireland since such citizenship also brought with it EU citizenship; ${ }^{3}$ (ii) the provisions of Protocol Article 3 addressing the CTA provid a degree of reassurance that these arrangements are now recognized in an international agreement; ${ }^{4}$ and (iii) Protocol Article 2 ensures that there be no diminution of rights as a result of the UK's exit from the EU. It is this third provision that this chapter primarily considers. Protocol Article 1 provides that its express objective is the protection of the 1998 Agreement 'in all its dimensions'.

This chapter focuses on how Protocol Article 2 addresses human rights and equality issues in Northern Ireland. This chapter also describes how the TCA supplements the Protocol in several respects, addressing some issues that were left unaddressed by the Protocol, in particular issues concerning the protection of labour and social rights (in the 'level playing field' provisions), and the status of the ECHR. These will be considered briefly in order to provide a more complete map of the new architecture of human rights and equality in Northern Ireland currently in place, without attempting to be comprehensive. Chapter 13 considers the role of the EU CFR. ${ }^{5}$

\subsection{Article 2 of the Protocol}

\subsubsection{Application}

Article 2 establishes obligations on the UK ('the United Kingdom shall ...'). The UK is bound by international law to implement the Protocol in good faith and in its entirety (Vienna Convention on the Law of Treaties (VCLT), Article 26), including Article 2. Neither Ireland nor the EU has obligations under Article 2, although Ireland

\footnotetext{
3 Chapter 16.

${ }^{4}$ Chapter 14.

${ }^{5}$ Chapter 13.
} 
and the EU are obliged to facilitate the UK in carrying out its obligations generally. ${ }^{6}$

The 'no diminution' obligation is not restricted to the protection of the rights of any particular group; in particular, Article 2 is not linked to citizenship, nor is it restricted to the rights of the 'people of Northern Ireland'. In referring back to the provisions of the 1998 Agreement, however, the scope of the protection of the rights is limited to those in the community," which is left undefined. Who, then, is included as within 'the community'? In the other parts of the 1998 Agreement, the term 'community' refers to those in Northern Ireland. In this part of the Agreement, however, that interpretation is less convincing, given that this part contains obligations on the Irish government to incorporate the ECHR into Irish law, an obligation that clearly cannot be described as relating to the 'community' in Northern Ireland. It would appear, therefore, that the term 'community' in this part of the Agreement may also refer to those on the island of Ireland, with important implications for the scope of Article 2, as we shall see.

\subsubsection{Interlocking Elements}

There are three interlocking elements in Article 2: (i) the general clause ('no diminution of rights, safeguards or equality of opportunity, as set out in that part of the 1998 Agreement entitled Rights, Safeguards and Equality of Opportunity'); (ii) the anti-discrimination clause ('including in the area of protection against discrimination, as enshrined in the provisions of Union law listed in Annex 1 to this Protocol'); and (iii) the provision dealing with domestic implementation requirements (including the reference to 'dedicated mechanisms' in Article 2(1)). In addition, these specific provisions must be seen as set in the broader general provisions of the WA and the Protocol, in particular those dealing with interpretation and enforcement, including international dispute settlement. Each of these elements will be considered in turn.

\subsubsection{General Clause}

There are three distinct elements to the general clause. First, the guarantee relates to 'rights, safeguards or equality of opportunity .... . Second, it

${ }^{6}$ Chapter 8.

7 'The parties affirm their commitment to the mutual respect, the civil rights and the religious liberties of everyone in the community.' 
relates only to those rights etc in that particular part of the Agreement entitled 'Rights, Safeguards and Equality of Opportunity' ('as set out in that part of the 1998 Agreement entitled Rights, Safeguards and Equality of Opportunity'). Third, the guarantee aims to ensure that 'no diminution ... results from [the UK's] withdrawal from the Union ...' The first two issues will be considered together, before turning to consider the third.

A preliminary issue as to the coverage of the general clause arises because of the way in which the relevant part of the Agreement is drafted. The first sentence of that part reads: '1. The parties affirm their commitment to the mutual respect, the civil rights and the religious liberties of everyone in the community. Against the background of the recent history of communal conflict, the parties affirm in particular ....' The relevant section of the Agreement then goes on to specify the set of particularized rights protected. It is unclear whether the general clause therefore protects all 'civil rights and religious liberties' or only the particularized rights ('right of free political thought' etc). If the former, the coverage of Article 2 is potentially very broad indeed: the Oxford English Dictionary definition of civil rights includes 'the political, social, and economic rights which are recognized as the entitlement of every member of a community and which can be upheld by appeal to the law'.

If the latter, then the 'rights' specified in the relevant section of the Agreement are: the right of free political thought; the right to freedom and expression of religion; the right to pursue democratically national and political aspirations; the right to seek constitutional change by peaceful and legitimate means; the right to freely choose one's place of residence; the right not to be discriminated against; the right to equal opportunity in all social and economic activity, in both the public and the private sector, regardless of class, creed, disability, gender or ethnicity; the right to freedom from sectarian harassment; the right of women to full and equal political participation; and the right of victims to remember as well as to contribute to a changed society.

Even if the 'civil rights' protected by Article 2 are limited to the rights listed in the Agreement, the protection of Article 2 also applies to certain 'safeguards' which are outside even the broadest definition of 'civil rights'. There are four safeguards in the relevant section of the Agreement. Three are relatively straightforward: the 'need to ensure that symbols and emblems are used in a manner which promotes mutual respect rather than division'; 'the importance of respect, understanding 
and tolerance in relation to linguistic diversity'; and continuing UK membership in the ECHR, combined with the provision of domestic remedies for alleged breaches of the Convention, an issue considered subsequently.

In addition to these, however, there is a further broader provision: 'Pending the devolution of powers to a new Northern Ireland Assembly, the British Government will pursue broad policies for sustained economic growth and stability in Northern Ireland and for promoting social inclusion, including in particular community development and the advancement of women in public life.' The reference to 'social inclusion' arguably refers to a broad swathe of socioeconomic protections. However, the commitment is time-limited and (with the establishment of the Assembly) may be seen as having lapsed. Given these uncertainties, the role of the TCA in addressing the "level playing field' issues of social and employment rights is of added importance.

These uncertainties aside, the restriction of Article 2 to the 'nondiminution' of rights and safeguards in the relevant part of the Agreement, and only those rights and safeguards, means that the socalled birthright provision of the Agreement (the right for the people of Northern Ireland to be British or Irish or both) is not included within the Article 2 obligation (or indeed elsewhere in the Protocol), although it is referred to in one of the Recitals to the Protocol, which means that it may be relevant to the interpretation of other provisions of the Protocol (including Article 2).

Turning now to the third element in the general clause, we have noted that the Article 2 obligation prohibits only any 'diminution [which] results from [the UK's] withdrawal from the Union ... '. Two main issues arise from this: (i) what elements of EU law (up to the end of the transition period) provided legal underpinnings to the rights protected in the relevant section of the Agreement (the Preamble to the Protocol refers to EU law's 'supporting framework') and (ii) when would any future diminution 'result from' the UK's exit?

It is not hard to visualize situations in which a rule of EU law would have enabled or facilitated the enforcement of 1998 Agreement rights obligations and in which that EU rule has been abrogated and not replaced after Brexit. So far as is known, however, there was no systematic mapping exercise undertaken of precisely what elements of EU law (up to the end of the transition period) provided legal underpinnings to the relevant 1998 Agreement rights and safeguards, and no official list has yet 
been published by official bodies in either the EU or the UK. It is clear that such a list would need to consider the full range of substantive Treaty articles, regulations, directives and provisions of the CFR that provided a 'supporting framework' for each of the 1998 Agreement rights and safeguards. 'Underpinning' thus refers to the substantive rules of EU law, but it also refers to the procedural and remedial rules of EU law that ensure or facilitate the full and efficient application and enforcement of the 1998 Agreement rights in Northern Ireland, for example the right to secure damages for breach of a rule by the state, and the right to have legislation suspended if it is held to be contrary to the Protocol.

When would any future diminution 'result from' the UK's exit? The appropriate question is whether but for the UK's exit that diminution would have been able to occur, legally. If the answer is negative, then Article 2's non-diminution obligation applies. This will be a mixed question of law and fact in each case. Unless, over time, all divergences end up being attributed back to Brexit as a matter of course, which seems unlikely, this aspect of the Article 2 obligation renders the protection accorded a wasting asset, since the longer any diminution is from the date of exit, the more difficult it may be to establish that but for that exit the UK would not have been in a position to reduce the level of protection provided.

A more particular question relates to the application of Article 2 to the continuing status of the ECHR in Northern Ireland. Would it be a breach of Article 2 for the UK to withdraw from the Convention? In my view it would not because of the 'supporting framework' criterion. Although we have seen that it is included as one of the 'safeguards' in the relevant section of the Agreement, we cannot say that the UK's membership in the Convention is underpinned by EU law, only by a political commitment. Given the limits of Article 2 in this respect, the provisions of the TCA concerning the status of the ECHR in UK law generally become of central importance. Two examples illustrate the method required in applying the general clause of Article 2.

\subsubsection{Example 1: EU Citizens' Eligibility to Vote in District Council Elections}

The first example concerns the eligibility to vote and to stand for election in Northern Ireland. The franchise for district council elections in Northern Ireland is to be found in the Elected Authorities (Northern Ireland) Act 1989 (as amended), section 1. This provides that British or Commonwealth citizens, citizens of the Republic of Ireland and citizens 
of other European Union (EU) countries are eligible to vote, in all cases provided they are aged eighteen or over on polling day, have been resident in Northern Ireland during the whole of the three-month period prior to the election, are registered to vote and are not otherwise legally excluded from voting. What if a future UK parliament deprived EU citizens resident in Northern Ireland of the right to vote in district council elections?

Several issues would need to be considered in determining whether this would amount to a breach of Article 2. First, it seems clear that three particular rights specified in the relevant part of the 1998 Agreement are engaged, viz 'the right to pursue democratically national and political aspirations', the 'right to seek constitutional change by peaceful and legitimate means' and the 'right of women to full and equal political participation'. Second, the right in question was underpinned by identifiable EU law that was in force in Northern Ireland during the relevant period. Article $8 \mathrm{~b} .1$ of the Treaty establishing the European Community (as amended by Title II of the Treaty on European Union) introduced a right to vote in 'municipal' elections by EU citizens resident in another member state. Two EU directives subsequently spelled out the detailed arrangements necessary to operationalize this right. ${ }^{8}$

Taken together, these establish voting rights and the right to stand for election for resident EU citizens in 'municipal' elections in the member states. EU citizens' rights to vote and to stand as a candidate under EU law are restricted to 'municipal' elections, which in Northern Ireland means district council elections. ${ }^{9}$ Furthermore, in the context of the implementation of the relevant Treaty provisions and directives ${ }^{10}$ identified, several provisions of the CFR apply: Article 11 Freedom of expression and information; Article 12 Freedom of assembly and of association; and, in particular, Article 40 Right to vote and to stand as a candidate at municipal elections. Finally, but for the UK's exit that right would still have to be provided for in Northern Ireland law. Any 'diminution' of that

${ }^{8}$ Council Directive 94/80/EC of 19 December 1994 laying down detailed arrangements for the exercise of the right to vote and to stand as a candidate in municipal elections by citizens of the Union residing in a Member State of which they are not nationals; and Council Directive 2013/19/EU of 13 May 2013 adapting Directive 94/80/EC laying down detailed arrangements for the exercise of the right to vote and to stand as a candidate in municipal elections by citizens of the Union residing in a Member State of which they are not nationals.

9 Art 2 Council Directive 94/80/EC of 19 December 1994, and Annex to Council Directive 2013/19/EU of 13 May 2013.

10 Art 51 CFR. 
right would have been contrary to EU law, if the UK had still been a member state of the EU.

\subsubsection{Example 2: EU Citizens Resident in Ireland Seeking to Reside in Northern Ireland}

In our second example, that there is an EU citizen who is not also an Irish citizen lawfully resident and working in Ireland. This person now wishes to take up employment in Northern Ireland. The provisions of Part 2 WA will not enable her to do so; nor will the provisions of the CTA, since she is not an Irish citizen. The UK authorities refuse her application to work in Northern Ireland. Prior to Brexit, under EU law, she could have relied on her free movement rights to work in Northern Ireland. Can she successfully argue that Article 2 prevents this diminution of rights?

Certain aspects of this case are clear: she had a Union law-based right which she now does not have. Although the right to free movement is an EU citizenship right found in EU law, the relevant part of the 1998 Agreement also protects 'the right to freely choose one's place of residence'. That appears broad enough to cover circumstances where the UK prevents someone who would have had the right to choose to reside in Northern Ireland before Brexit based on EU rights and is now no longer able to do so because of UK withdrawal.

The diminution of that right resulted from the UK's withdrawal (using the 'but for' test). The 'no diminution' obligation applies to the UK government, which is now refusing her entry to work. Article 2 is only binding on the UK, so Article 2 would not help a Northern Irelandresident EU citizen cross the border in the other direction. So Article 2 would apply only, potentially, to travellers going North, not the reverse. It would not constrain the EU or Ireland.

The key question then becomes whether the person seeking to use Article 2 is within 'the community' to which this part of the 1998 Agreement applies. There appear to be three possible interpretations: a narrow reading (it's only the people in Northern Ireland); a broader reading (it's all the people in Ireland and (possibly) the UK); and the broadest reading (it's all people in the EU, or possibly the whole world). The broadest reading is unconvincing, but so too is the narrowest reading.

As suggested above, 'community' in other parts of the 1998 Agreement refers to those in Northern Ireland (such as in Strand 1, and Policing), but in the human rights, etc section that is not so clear, given that there is a part of that section devoted to the protection of 
human rights in the South (the responsibilities of the Irish government, which was inserted at the behest of the unionist negotiators). Ironically, this seems to imply that the 'community' in that section has been expanded to include at least those in the South, given that the reference to the 'community' prefaces all the parts of that section, not just the parts dealing with Northern Ireland. If so, that would indeed mean that non-Irish/British residents of Ireland would continue to enjoy the right to reside in Northern Ireland as before Brexit, as a result of Article 2 .

\subsubsection{Anti-discrimination Clause}

The second element in Article 2, the anti-discrimination clause, needs separate treatment. It provides that there shall be 'no diminution of ... equality of opportunity, as set out in that part of the 1998 Agreement entitled Rights, Safeguards and Equality of Opportunity ..., including in the area of protection against discrimination, as enshrined in the provisions of Union law listed in Annex 1 to this Protocol .... The directives included are restricted to what $\mathrm{EU}$ law considers the key 'antidiscrimination' directives.

The description of the directives listed as constituting 'Union law' has considerable significance. This is because Article 4(3) WA stipulates that the provisions of the Agreement referring to 'Union law or to concepts or provisions thereof shall be interpreted and applied in accordance with the methods and general principles of Union law'. This means, for example, that the interpretation of what the directives require must be undertaken taking into account all of the interpretative elements that the Court of Justice of the European Union (CJEU) would apply, including the general principles of EU law and, where relevant, the CFR, since the CJEU may draw upon the CFR if required to rule upon the meaning of the directives. Article 13(2) of the Protocol places no temporal limitations on this obligation. Northern Ireland courts would, therefore, also be required to follow post-transition CJEU case law by reason of that provision.

We have seen that the designated EU law listed in Annex 1 includes only the substantive anti-discrimination directives. The drafters of the Protocol have relied, therefore, on a distinction between the antidiscrimination directives (included in Annex 1) and directives that address broader issues of equality of opportunity and social policy (not included in Annex 1), such as the Part-Time Work Directive, the 
Maternity and Parental Leave Directive and the Pregnancy Directive. This does not mean, however, that these additional directives are irrelevant to the operation of Article 2 because, although they are not listed in the Annex, they do constitute 'underpinnings' to the protection of equality of opportunity and are thus to be considered in the application of the general clause.

Article 2 provides: 'The United Kingdom shall ensure that no diminution of ... equality of opportunity, as set out in that part of the 1998 Agreement entitled Rights, Safeguards and Equality of Opportunity results from its withdrawal from the Union ....' The Agreement's listed rights include the 'right to equal opportunity in all social and economic activity, in both the public and private sectors, regardless of class, creed, disability, gender or ethnicity'. The Part-Time Work Directive, the Victims Directive, the Maternity and Parental Leave Directive, the Pregnant Workers Directive and specific EU measures aimed at protecting the rights of persons with disabilities are measures that underpinned this right in Northern Ireland law, and thus any diminution from the level of protection accorded by these provisions will run contrary to the general clause of Article 2, even though it will not run contrary to the provisions of the anti-discrimination clause.

\subsubsection{International Governance Arrangements}

The governance of Article 2 may be set out only briefly here because the compliance mechanisms applying to Article 2 are set in the context of the Protocol as a whole. Unusually, as regards trade agreements generally, the same provisions for international interpretation and enforcement apply to Article 2 as apply to customs, trade and regulatory issues. The Specialised Committee on Ireland-Northern Ireland and the Joint Committee (JC), discussed in Chapter 4, also apply to Article 2. (A potentially significant difference, however, is that two independent public bodies in Northern Ireland, the Northern Ireland Human Rights Commission (NIHRC) and the Equality Commission for Northern Ireland (ECNI), have a role in providing information on the implementation of Article 2 to the Specialised Committee.) Likewise, the international arbitration panel, discussed in Chapter 5, is empowered to determine violations of Article 2 in the event of a dispute arising which cannot be settled otherwise, with the CJEU having final jurisdiction over determining any issue of EU law. The ultimate sanction for violation of Article 2, as with the other provisions 
of the Protocol, is suspension of the WA as a whole, except for provisions dealing with citizens' rights.

\subsubsection{Domestic Governance Arrangements}

The requirements for the domestic implementation of Article 2 differ, however, from those that apply to the Single Market and Customs provisions of the Protocol, in three particular respects. First, the Northern Ireland Assembly 'consent principle' does not apply to Article 2, so even if the Assembly were to vote to terminate the Protocol, it would apply only to Articles 5 to 12, not Article 2. Second, the ability (and, in the case of decisions by the court of law resort, the obligation) of the domestic courts to refer issues of EU law to the CJEU under the preliminary reference procedure does not apply to Article 2 issues. Third, there is an important role for the NIHRC and the ECNI in overseeing the domestic implementation of Article 2, a role that has no equivalent with regard to the other provisions of the Protocol and is an important part of the domestic 'dedicated mechanism' required by Protocol Article 2(1). A role for these Commissions is recognized in Protocol Article 2(2), but the details are set out in the European Union (Withdrawal Agreement) Act 2020 (EUWAA). ${ }^{11}$ This provides for both Commissions to have the powers to monitor implementation, to have standing for taking judicial review in its own name, and to have the ability to support judicial review by other parties. This has been accompanied by increased staff and additional funding from government to support these activities.

Section 7A of the European Union (Withdrawal) Act 2018 (as amended) (EUWA) also applies to Article 2, as it does to the whole of the Protocol. As a result, Article 2 applies to both the Westminster Parliament and the UK government. In addition, there is specific provision regarding the obligations of the devolved institutions of government in Northern Ireland. As regards Article 2, the primary obligations include legislating in a manner that is consistent with the Protocol's provisions on rights, ${ }^{12}$ and tracking changes in EU law. ${ }^{13}$ If the Assembly/Executive refuses to introduce tracking of changes, the Secretary of State is empowered to override that refusal and legislate directly. If both the

11 EUWAA 2020, Schedule 3.

12 Art 2 of the Protocol; and NI Act 1998, ss 6(2)(ca) and 24(1)(aa).

13 Art 13 of the Protocol and NI Act 1998, s 26. 
Assembly and the Secretary of State were to refuse to legislate, judicial review would be almost certain.

\subsubsection{Direct Effect}

As with other provisions of the WA and the Protocol, there is room for debate as to whether and, if so, how far Article 2(1) has 'direct effect'. 'Direct effect' has two somewhat different meanings: (i) that a legal rule must be applied by a national court, even in the absence of implementing measures, against all parties; and (ii) that natural and legal persons are able to rely directly on the rule in domestic UK courts to their benefit. Article 4(1) WA states that provisions of 'Union law' made applicable by the Agreement 'shall produce in respect of and in the United Kingdom the same legal effects as those which they produce within the Union and its Member States'. Article 4(1) continues: 'Accordingly, legal or natural persons shall in particular be able to rely directly on the provisions contained or referred to in this Agreement which meet the conditions for direct effect under Union law', the test for which is whether the provision is 'clear, precise and unconditional'.

It may be necessary to distinguish between the direct effect of the general clause and the anti-discrimination clause. Of the two, the antidiscrimination clause most directly engages Article 4(1) WA, given that Annex 1 specifically refers to 'Union law', in the form of the antidiscrimination directives. The anti-discrimination directives have consistently been held to have vertical direct effect, and so it would appear that at least the anti-discrimination clause (together with the Annex) is directly effective against the UK. As regards the direct effect of the general clause, there is more room for debate because it is arguably less clear and precise than the anti-discrimination clause, and so on its wording it is arguable that it does not meet the threshold for direct effect in EU law. Because of this uncertainty, ministerial statements in the House of Lords and the UK government's Explainer on Article $2^{14}$ take on an added importance. Both in a statement in the House of Lords ${ }^{15}$ and

\footnotetext{
14 'Information about the UK Government's Commitment to "No Diminution of Rights, Safeguards and Equality of Opportunity" in Northern Ireland: What Does It Mean and How Will It Be Implemented?' (7 August 2020) www.gov.uk/government/publications/ protocol-on-irelandnorthern-ireland-article-2.

15 Lord Duncan of Springbank (Northern Ireland Office Minister):
}

The Government also considers that Article 2(1) of the Protocol is capable of direct effect and that individuals will therefore be able to rely directly on 
in its Explainer on Article 2, ${ }^{16}$ the UK government accepted the direct effect of Article 2 as a whole. Given the importance of such statements as indicative of the understanding of the WA, ${ }^{17}$ under the VCLT's approach to interpretation, such statements are likely to prove determinative.

Should this not prove to be the case, then the issue arises as to whether the Francovich rule (state liability in damages for the incorrect adaptation of national law) applies in the event of a breach of Article 2's general clause. The difficulty here is that such damages appear to have been abolished specifically by EUWA $2018 .{ }^{18}$ The issue is whether, despite this, state liability in damages remains available in Northern Ireland. We have seen that the Protocol protects certain rights from diminution, and that those rights have, in part at least, been underpinned by Union law. Thus far, we have been concerned with substantive EU law, but we should also include EU procedural and remedial law, including the Francovich rule, which underpins the substantive rights. These substantive rights would be much less well protected if the Francovich rule were no longer to apply. The substantive rights would be 'diminished' if the procedural and remedial dimensions of the right were taken away. The 'no diminution' obligation applies not only to the substantive rights but also to the procedural and remedial dimensions of those rights, including the Francovich rule, a position that is supported by the judgment of the European Free Trade Association (EFTA) Court in an analogous case. ${ }^{19}$ Since the Protocol requires this, section 7A of the 2018 Act overrides the prohibition on Francovich damages in the rest of the UK. The effect of the 'no diminution' rule is to create a lex specialis as an exception to the general principle of 'no Francovich damages' in the EUWA.

\subsection{Trade and Cooperation Agreement}

There are two main sets of provisions of the TCA which need to be taken into account in reaching a balanced judgment on the degree of protection

this article before the domestic courts. Individuals will be able to bring proceedings independently or, where the case meets certain criteria, with the assistance of the Northern Ireland Human Rights Commission or the Equality Commission for Northern Ireland.

(WA, 28 January 2020, www.parliament.uk/business/publications/written-questionsanswers-statements/written-question/Lords/2020-01-14/HL404/)

16 ،... individuals will also be able to bring challenges to the Article 2(1) commitment directly before the domestic courts' Explainer, para 29.

17 See Chapter 7.

18 See Chapter 9.

19 Case E-9/97 Sveinsbjörnsdóttir [1998] EFTA Court Reports 95 (para 48). 
accorded to rights in Northern Ireland following the departure of the UK from the Union, namely the so-called level playing field provisions and the human rights provisions. ${ }^{20}$ Though quite modestly, these provisions partially address the failure of the Protocol to address labour and social rights explicitly, and the role of the ECHR in Northern Ireland. It is important to note, however, that, unlike the provisions of the Protocol, these provisions are specifically stated not to be directly effective. ${ }^{21}$

\subsubsection{Level Playing Field Provisions}

These provisions were designed to ensure fair competition between the $\mathrm{EU}$ and the UK, and include commitments not to regress from labour, social, environmental and climate standards. These restrictions are unlikely to prove constraining, except in quite special circumstances. Article 6.2 provides only that '[a] Party shall not weaken or reduce, in a manner affecting trade or investment between the Parties, its labour and social levels of protection below the levels in place at the end of the transition period, including by failing to effectively enforce its law and standards'. So, too, either side may take 'rebalancing measures' if material impacts on trade or investment arise as a result of significant divergence. Article 8.3 appears to apply all the International Labour Organization (ILO) Conventions that the UK and the member states of the Union have respectively ratified, as well as the provisions of the European Social Charter that, as members of the Council of Europe, the member states of the Union and the UK have accepted, but the obligation is weaker than it may appear; each party only 'commits to implementing' these provisions, which falls considerably short of their being obligated to comply with them.

\subsubsection{Human Rights Provisions}

There are two main sets of human rights provisions: the general rules on human rights found in Articles 763 and 771, together with Article 772, and the special rules on human rights in the criminal justice context detailed in Article 524.

${ }^{20}$ For the sake of completeness, Art 285: Environmental, social and labour considerations provides a degree of protection for procurement linkages in Northern Ireland. See further Chapter 22.

${ }^{21}$ Note, however, the caveat in Chapter 3 that these provisions may be regarded as directly effective under UK domestic law. 
As a result of the general rules, the parties 'shall continue to uphold the shared values and principles of democracy, the rule of law, and respect for human rights, which underpin their domestic and international policies. In that regard, the Parties reaffirm their respect for the Universal Declaration of Human Rights and the international human rights treaties to which they are parties.' This provision on human rights is described as constituting 'essential elements of the partnership established by this Agreement'. If either party considers that there has been a serious and substantial failure by the other party to fulfil any of the obligations that are described as essential elements, it may decide to terminate or suspend the operation of the Agreement or any supplementing agreement in whole or in part, subject to a delay to allow for negotiations between the parties to take place, and to the measures being proportionate. The significant limitation on the applicability of these provisions is that 'for a situation to constitute a serious and substantial failure to fulfil any of the obligations described as essential elements ..., its gravity and nature would have to be of an exceptional sort that threatens peace and security or that has international repercussions'.

The special rules on human rights in the criminal justice context appear somewhat more robust. The co-operation in the criminal justice context is said to be 'based on the Parties' and member states' longstanding respect for democracy, the rule of law and the protection of fundamental rights and freedoms of individuals, including as set out in the Universal Declaration of Human Rights and in the ECHR, and on the importance of giving effect to the rights and freedoms in that Convention domestically'. This constitutes the first time in either the WA or the TCA that the ECHR is mentioned specifically, and its domestic implementation.

As well as being more specific than the general provisions discussed previously, these specific provisions are also subject to a broader compliance regime. Each party 'may at any moment terminate [the criminal justice co-operation measures] by written notification' for breach of these protections. There is no requirement that the breach be of the exceptional sort required for a breach of the general human rights obligations, and it is clear that withdrawal from the Convention and certain specified Protocols (1, 6 and 13) is itself sufficient to justify termination of this part of the TCA. Where there are 'serious and systemic deficiencies' by a Party regarding 'the protection of fundamental rights or the principle of the rule of law', the other Party may also suspend (rather than terminate) this Part of the TCA. 


\subsection{Conclusion}

Given the relative weakness of the human rights provisions of the TCA, Article 2 of the Protocol is likely to take on increased significance, but how far it will prove effective remains to be seen. On the one hand, Article 2 might come to be seen as less than the sum of its parts, or at least less than it first appears. On the other hand, Article 2 could become the foundation of a unique dispensation for Northern Ireland. Neither of these assessments is likely to be borne out in practice; it is more likely that it could come to be seen in practice as of limited application, but of surprisingly significant depth when it does apply. At the time of writing, at least one case is pending that may begin to indicate how the courts will consider Article 2 in the future. ${ }^{22}$

${ }^{22}$ In the Matter of an Application by SPUC Pro-Life Ltd (due to be heard in the Northern Ireland High Court in October 2021, involving the application of Article 2 in support of a claim of disability discrimination in abortion). This case is discussed in 'Update: Developments from July 2021 to September 2021' at the front of this book. 